\title{
Triple Helix and Decentralization Approach: Management of School Operational Assistance Funds
}

\author{
Jamaluddin Ahmad $^{1, *}$, Andi Astinah Adnan ${ }^{1}$, Muhammad Hanafi ${ }^{2}$, Yusuf Qamaruddin ${ }^{3}$ \\ ${ }^{1}$ Department of Public Administration, Universitas Muhammadiyah Sidenreng Rappang, Indonesia \\ ${ }^{2}$ Department of Indonesian Language Education, Universitas Muhammadiyah Sidenreng Rappang, Indonesia \\ ${ }^{3}$ College of Management, Universitas Muhammadiyah Palopo, Indonesia
}

Received July 13, 2020; Revised August 6, 2020; Accepted September 17, 2020

\section{Cite This Paper in the following Citation Styles}

(a): [1] Jamaluddin Ahmad, Andi Astinah Adnan, Muhammad Hanafi, Yusuf Qamaruddin , "Triple Helix and Decentralization Approach: Management of School Operational Assistance Funds, "Universal Journal of Educational Research, Vol. 8, No. 10, pp. 4826 - 4834, 2020. DOI: 10.13189/ujer.2020.081054.

(b): Jamaluddin Ahmad, Andi Astinah Adnan, Muhammad Hanafi, Yusuf Qamaruddin (2020). Triple Helix and Decentralization Approach: Management of School Operational Assistance Funds. Universal Journal of Educational Research, 8(10), 4826 - 4834. DOI: 10.13189/ujer.2020.081054.

Copyright $\bigcirc 2020$ by authors, all rights reserved. Authors agree that this article remains permanently open access under the terms of the Creative Commons Attribution License 4.0 International License

\begin{abstract}
Improving the quality of education can be implemented in various ways. This study aims to analyze the triple helix approach in the management of School Operational Assistance funds which are decentralized to schools. Decentralized planning, organizing, directing and controlling the process as stipulated in the Regulation of the Minister of Education and Culture of the Republic of Indonesia concerning Technical Guidelines for Regular School Operational Assistance. Data collection was carried out through questionnaires and in-depth interviews with 35 respondents, namely the principal, and the administrator of the secondary and vocational school committee in Sidenreng Rappang Regency. Use the Nvivo-12 plus program assistance to process data from interviews, documents and explanations from the Minister of Education and Culture. The results showed that the authority and deconcentration and devaluation authority dominated the process of using school operational assistance funds. The main finding of this study is the importance of the triple helix approach of universities, industry, and local government in the area of decentralization of authority for channelling school operational assistance funds. This finding is supported by optimizing the involvement of the triple helix in school committee members. The implications of the triple helix approach will ensure accountability and transparency in the management of school operational assistance funds because they are stakeholders in the education sector, especially in secondary and vocational schools.
\end{abstract}

Keywords Triple Helix, Decentralization, School Operational Assistance

\section{Introduction}

\subsection{Decentralized Education Management}

Decentralization theory is one theory that can be used in analyzing policy change. Policy changes in government occur because of changes in leadership. Decentralization is about shifting in the locations of those who govern, about transferring authority from those who are in one location or level vis-à-vis educational organizations, to those at another level. Decentralization is the delegation of authority to plan, make decisions and manage central government functions to local governments [1], [2]. Decentralization is formally embedded in governance [3]. The benefits of decentralization include adjusting planning to regional needs, cutting out unnecessary procedures, formulating programs more realistically and more effectively [2]. Decentralization is often defined in four degrees of transfer of authority: deconcentration, delegation, devolution, and privatization [1], [2].

To distinguish them will be described in four parts. First, deconcentration is the transfer of workload from the central government to central government staff in the region. The 
team is not given the authority to make decisions outside of established functions [2]. Deconcentration is the transfer of administrative tasks from the central state to the state, usually through the establishment of regional or local field offices [4]. The education department to the provincial department or the school as an administrative level is called the deconcentration process [1]. Second, delegation is the delegation of decision making and management authority to specific functions for organizations that are only under the indirect control of central government ministries [2], [5], [6]. Delegate authority for public education to representatives of the Minister, who is located in each state or provincial capital [1]. Third, devolution, namely the transfer of power to geographical units of local governments that are outside the formal command structure of the central government [2]. Devolution is different from deconcentration and delegation because devolution uses other units or parts that are not the command line of the central government. However, devolution is often accompanied by deconcentration [4] in its application. In the devolution education sector means the transfer of authority from the level of high authority to lower outside the education sector [1]. Fourth, privatization, which is a form of decentralization that is managed by the private sector and is free to regulate itself [1], is often associated with economic aspects [3]. Therefore, in the education sector, there are three types of schools namely private schools subsidized by the state following government guidelines, schools that are relatively autonomous but charge fees, and schools are funded by private and publicly controlled [1].

Based on the decentralization conditions, leaders want to remain in power. Because each leader depends on the support of several groups of domestic actors to maintain his leadership position, leaders tend to pursue policies favoured by their core social support groups [7]. The importance of leadership is involved in changing the rules so that success can be emulated by other groups advocating for policy change [8]. The change of the Minister of Education and Culture of the Republic of Indonesia for the period 2019-2024 has implications for policy changes in the distribution of school operational assistance funds (BOS) in Indonesia so that authority is more decentralized. However, the difference was felt to be very significant because the Minister was among the millennial generation who had no teacher or lecturer background that had become a tradition in the Ministry of Education and Culture. But the Minister chosen by the president is a former chairman of the company Star Up (Gojek) with an age that is still classified as millennial. This is interesting in this research as well as being unique. The millennial as uniquely positioned to serve as (a) educator and (b) as a learner (end-user).

Various research results indicate the importance of delegating authority in public services. Research is conducted in more than 72 countries regarding quality standards, implementation of autonomy, and public satisfaction in public services. This research advances our understanding of the role of administrative autonomy in citizen satisfaction and provides implications for the institutional designs that can benefit performance assessment [9]. The education system reform in China also shows the same thing, namely reforming the management system, while strengthening macro-management, firmly implementing simplified administration and decentralization, and increasing the level of autonomous schools [10], [11]. Similarly, the results of research in Pakistan on The Allocation of Authority in Organizations: A Field Experiment with Bureaucrats found that the importance of organizational design and anti-corruption policies must balance agency issues at different levels of the hierarchy [12]. Therefore, it is very important to delegate public services that make up the hierarchy.

Some examples of tuition subsidies can be described as follows. The administrative structure of the initial assistance scheme, the Youth Education Fund (YEF), was very decentralized, with a supervisory board and steering committee as the main organizational actor in Denmark used as an example [13]. Official development assistance (ODA) in Africa is still a matter of debate, therefore recommending that ODA for scholarships and pure participation rates one year before the age of official primary school entrance and the percentage of primary school teachers trained should be increased in other cases [14]. The various programs whose names differ from one country to another, but the aim is how to improve the quality of education through government assistance in financial form.

Likewise, Indonesia issued a school operational assistance fund (BOS) policy to help with school operational costs and improve the accessibility and quality of learning for students. Helping school operational costs are implemented in a decentralized way. Improve the accessibility and quality of learning, especially in early education so that later can help expedite students facing the college. This has been stipulated in Minister of Education and Culture Regulation number 8 of 2020 as a continuation of previous regulations.

The authority given to the BOS Team is to ensure the correctness of data in the primary data of educators, monitor and evaluate the use of BOS funds. However, it is not explained how the authority mechanism is carried out as a result of research by several scholars explaining the importance of clarity about the authority mechanism. Private and public authority interactions and the functional quality of sustainability governance: Lessons from conservation and development initiatives in Tanzania found that clear division of responsibilities, coupled with material incentives for society and equal and transparent distribution of benefits, were the main positive contributors to functional quality [3]. The same research 
conducted at Abu Dhabi University on employees found that the level of administrative empowerment implementation has a high correlation on decision-making skills related to problem-solving provided clear delegation of authority is given [15]. Delegation of authority clearly guarantees the resolution of the problem [16], [17].

This is consistent with the explanation of the Minister of Education and Culture: "that if we give autonomy we give flexibility it does not mean that accountability and transparency are not important, it is even more important. Transparency and accountability become more important the more freedom given in the allocation of their use the higher must be transparency and accountability. So in 2019 we only received about $53 \%$ of the schools reporting through our online system that the use of the boss was like what arrived at the Ministry of Education and Culture, starting in 2020 it was a condition for acceptance, so if for example, after that the Minister said if we had three channelings. If the Ministry of Education and Culture does not receive the BOS report via online such as the website, the first and second stages of the third will not be transferred, so we have to have $100 \%$ of all schools reporting online to receive the last third shipment. Yes, this is the rule we tightened up so that previously 53\% reported that we wanted that number to reach $100 \%$."

\subsection{Triple Helix Approach}

Theories about the Triple Helix were originally popularized by Etzkowitz and Leydesdorff as a method of innovation-based policy development [18]-[20]. This theory emphasizes the importance of creating a synergy of the three poles, namely intellectuals, business, and government [18], [21]. University and industry or private collaboration is one of the most discussed topics in this field [22]. This emphasizes the importance of interaction between universities and companies in facilitating regional innovation capabilities [22], [23]. The triple helix that was important at first was for regional innovation programs [18], [23]. Regional Innovation Systems is an integral part of the National Innovation System [18]. As happened in China with the concept of the Chinese national innovation system [22]. This system focuses on building rational organizations at different stages [19]. The functions that need to be handled by a triple helix organisation in an institutional environment are the space of knowledge, space of consensus, and space of innovation [6], [20].

The University is a space of knowledge or a centre of expertise [6], [20] occupied by intellectuals. These intellectuals are the preparation of human resources that will develop the country and region [11]. They are preparing to build capacity development in teaching and research [24]. The University researches the market or environmental needs, universities as users of high school and vocational high school graduates [25]. Therefore, the University and its intellectuals can provide suggestions for improvement based on research results, as well as having the interests of prospective students. The point is that universities are placed at the centre of the analysis [20], [26] which will create innovation or progress [27]. The University has a dedicated space to get high-quality prospective students.

Business or industry determines future economic activities [24], company or industry as the use of graduates [6] who have knowledge and innovation sourced from universities or schools [28]. They must understand business ethics [29] and workforce needs in business and industry. Business and industry as a centre for entrepreneurship incubators [26], [30]. Businesses and industries have an interest in acquiring company assets and taking opportunities and collaboration benefits [31], specifically the required human resource standards [32]. Business and industry can also be partners and donors [3], [27], which are the needs of schools. The need for school facilities and infrastructure requires collaboration with business and industry. The point is that business and industry collaboration is needed to improve the quality of education in schools.

Finally, the government, in this case, the regional government there will be challenges of coordination vis-à-vis local and regional governments, because of the principle of local self-government [5]. Budget policies are of particular interest to local governments in the implementation of power and authority resulting from decentralization [33]. So a collaboration framework is needed to set the local government partnership strategy [34]. Local government has a strategic interest to promote the performance, role and quality of local government in regional development [35], especially the education sector. The provincial government provides education infrastructure [36], universities build collaborative research and innovation, and business and industry help use human resources.

Rational organizations will certainly consider the competencies of each who contributes to problem-solving, meaning that competence understands millennial generation education problems. The term millennial was first sparked by William Strauss and Neil in their book titled Millennial Rising: The Next Great Generation [37]. This generation was born from 1981 until now, with a greater number of internet users in Indonesia [38], [39]. Pre-born generations of the first generation are known, such as Generation X (1965-1980) and the baby-boomer generation (1946-1964) is also considered to be influenced by seminal events in their own era [40].

Decision-makers in the field of education, especially government-private - universities should pay attention to the Millennial Education Approach. Millennial generation needs are of course related to information technology such as social media. Social media (SM) as defined by Kaplan and Haenlein is "a group of Internet-based applications that are built on the ideological and technological foundations 
of Web 2.0, and allow the creation and exchange of user-generated content" [41]. To understand these needs, the involvement of the triple helix is very helpful so that school operational assistance funds are more flexible, effective, efficient, accountable, and transparent. As the Minister of Education and Culture Regulation number 8 of 2020 article 3 states that the use of regular boss funds is carried out based on the principles of flexibility, effectiveness, efficiency, accountability, and transparency.

\subsection{School Committee}

School Committees are independent institutions consisting of parents or guardians of students, school communities, and community leaders who care about education. Understanding the school committee is an independent body that provides a forum for the community to improve the quality, equity, and efficiency of education management and teaching and learning process not only in the school environment but outside the school environment as well. School Committee is an agency or a non-political and profit institution established based on the democratical conference by the education stakeholders at school grade as the representative of various elements which is responsible for the increase of both educational process and result [42]. School Committee is an independent body that accommodates community participation in order to improve the quality, equality and efficiency of education management in education units, both in pre-school education, school education channels, and education channels outside of school [43].

In article 3 of the regulation of the Minister of Education and Culture of the Republic of Indonesia, number 75 of 2016 the school committee is tasked with giving consideration in determining and implementing related education policies; school program policies, school income, and budget plans, criteria for school performance, criteria for educational facilities in schools, criteria for collaboration with other parties. In addition, it also raises funds and other educational resources from the community, oversees the implementation of education, follows up complaints, suggestions, criticisms, and aspirations from students' parents or guardians, and the community.

From this explanation, according to the authors, the involvement of the triple helix in managing school operational assistance in the form of school committee members can guarantee flexibility, effectiveness, efficiency, accountability, and transparency. This makes sense because the government - universities - the private sector understands education management very much. The government with its policies will better understand the needs of schools, communities and the private sector. Higher education with its expertise better understands innovation, creativity, responsiveness, competitiveness, and cooperation. The private sector better understands the human resources needed in a competitive environment full of uncertainty. This is what the Indonesian government aspires to with the concept of "freedom of learning" through one of the Ministerial Regulations number 8 of 2020 concerning technical guidelines for regular school operational assistance. Understanding the role of administration in citizen satisfaction and providing implications for safety designs that can support the achievement of performance [9].

\section{Materials and Methods}

Data were collected through in-depth interviews and questionnaires with 35 school principals and secondary school committee administrators in Sidenreng Rappang Regency. Use of the Nvivo-12 plus program assistance to process data from interviews, documents, and explanations from the Minister of Education and Culture. This study uses quantitative descriptive methods, representing methods to discuss and understand the meaning proposed by each respondent. The research subjects were determined by using purposive sampling as applied to increase the number of research subjects when more in-depth information was needed.

As a research method used is descriptive quantitative, by studying the results of the questionnaire and the results of in-depth interviews. The validity of the research data was first checked. In the research here, to get comprehensive data, triangulation is used by combining all data from various sources in various ways and at various times. In addition, in order to gain confidence, the transcription of the question was re-checked by each respondent for every word that was mistyped or an idea that was not confirmed. The data obtained were analyzed and displayed descriptively. The data analysis technique used is the result of questionnaires and in-depth interviews made in the form of descriptive images and tables, then analysed using the theories described earlier in the literature review section.

\section{Results and Discussion}

The results of the processing of the Nvivo 12 plus are based on interview results and the contents of the Indonesian Minister of Education and Culture regulation, Explore the Sunburst Explorer Hierarchy Chart show that $40 \%$ of the materials are discussed deconcentration, following $37 \%$ devolution, $13 \%$ delegation, and $10 \%$ privatization of the number of nodes 163 . 


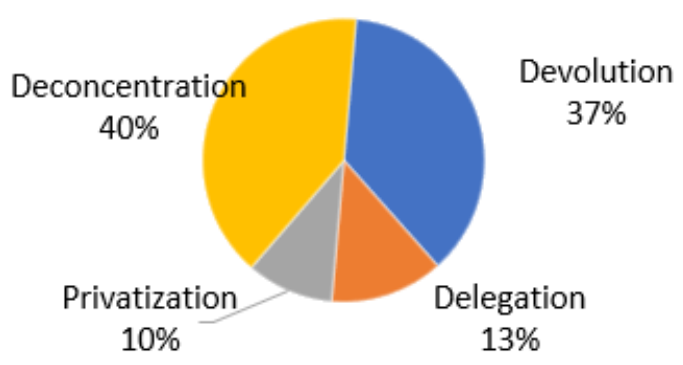

Figure 1. Processed Data Results

Based on available data in the management of school operational assistance funds according to Minister of Education and Culture Regulation No. 8 of 2020 article 9 paragraph 2 gives great authority to schools to finance the operational implementation of education. For example, free to determine the purchase of office stationery, textbooks, laboratory equipment, and teacher consumption. But it is not allowed to make rules in the form of policies other than financing the specified components. It is very clear to school principals, teachers and school committees which financing components are permitted and which financing components are not permitted. For Principals (Local), this is decentralized.

Based on the literature review of the following decentralization efforts from the following countries. Research in Italy and France found that deconcentration influences effectiveness and even effectiveness is strongly related to policy and management capacity [4]. Although the study focuses on culture, culture is relevant to knowledge and education [27], [44]. Also, research in India found that migrants can obtain education by deconcentrating public services. This is a particular challenge for migrants (very mobile, temporary, etc.) in accessing education [45]. Of course, this is highly expected by the Indonesian government through the policy of channelling school operational assistance funds.

Based on an interview with one of the school principals, it was stated that "the procedure for sending school operational assistance funds is sent directly to the school account, no longer through a local government account". This was also acknowledged by the Minister of Education and Culture stating that: "the policy of the ministry of education and culture is to directly transfer school operational assistance to the accounts of each school with different amounts, according to the number of students in DAPODIK (basic education data)." The data are reported annually according to each school's new school year as determined by the Ministry of Education and Culture. Principals in the management of school operational assistance funds must comply with the provisions of the Minister of Education and Culture Regulation No. 8 of 2020 concerning guidelines for channelling school operational assistance funds.

The decentralization of education management in Indonesia, particularly the use of school operational assistance funds, is strongly reflected in the organizational structure. The governor formed the school operational fund utilization team for the province. The district head or mayor forms the school operational fund utilization team at the district level. Specifically, for groups in senior high schools and vocational high schools developed and under the coordination of the provincial government. At the same time, it gives authority to monitor and evaluate the management of school operational assistance funds according to their jurisdiction and level.

Based on the data in Figure 1, decentralization is in the form of devolution. The granting of authority from the central government to regional governments is very clear in Article 14 paragraph 1 that the management and reporting of the use of regular school operational assistance funds are carried out by Schools and Local Governments following their respective authorities. The use of monthly operational assistance funds must approve agreements and joint decisions between the school principal, teachers, and School Committee. The results of the agreement are issued in the form of minutes of the meeting and signed by the meeting participants. Likewise, decentralization in the way of deconcentration. Schools must comply with guidelines for the distribution of school operational assistance funds that have been regulated by the provincial government. The provincial government is representative of the central government in regional or local [4]. In decentralization in the form of delegation, the results of the interviews were limited to the socialization activities carried out by the provincial education office branches in each region. Delegation of authority to the autonomy of types and amounts of use of school operational assistance funds rests with the school principal, teachers, and school committees. Likewise, in decentralization in the form of privatization, senior high schools and vocational high schools are relatively autonomous to collect fees because they have been assisted by the central government through school operational assistance funds. So it differs from the concept of privatization which is managed by the private sector and is free to regulate itself [1].

This authority reinforces the concept of devolution, inviting several research results that explain the importance of devolution. Devolution is a promising tool for improving the management of objectives, delegated decision authority and reported performance management [46], [47]. The granting of authority from the central government to schools further emphasizes the purpose of managing BOS funds. For example, table 1 illustrates the authority in the form of devolution of BOS fund management for the payment of honorariums for teachers and education personnel based on the Minister of Education and Culture Regulations [48].

As an illustration of the distribution of the use of school operational assistance funds for the payment of teacher and employee salaries, the maximum use of school operational 
assistance funds from each year vary. This is caused by changes in leadership that occur in the ministry of education and culture. According to Regulation number 26 of 2017, the maximum use between public schools and private schools is $15 \%$ of all funds received by schools. But experiencing a difference after 2018 , namely for private schools can be used up to 50\%. In 2019 there were two changes to the rules, namely Regulation Number 03 of 2019 where the distribution is the same, namely $15 \%$ for all schools, both public and private schools. However, in the second amendment, namely Regulation number 18 of 2019, the difference between public and private schools is $15 \%$ vs $30 \%$. Finally, Regulation number 08 of 2020 re-equates and even increases with the same amount of funds, which is $50 \%$, both public and private schools.

Table 1. Amount Maximum of Honor Payment to BOS Funds

\begin{tabular}{lcc}
\hline & $\begin{array}{c}\text { Public } \\
\text { school }\end{array}$ & $\begin{array}{c}\text { Private } \\
\text { school }\end{array}$ \\
\hline Regulation number 26 of 2017 & $15 \%$ & $15 \%$ \\
Regulation number 01 of 2018 & $15 \%$ & $50 \%$ \\
Regulation number 03 of 2019 & $15 \%$ & $15 \%$ \\
Regulation number 18 of 2019 & $15 \%$ & $30 \%$ \\
Regulation number 08 of 2020 & $50 \%$ & $50 \%$ \\
\hline
\end{tabular}

Based on the data in table 1 when viewed from the four dimensions of decentralization, there have been different variations over the past five years, particularly in the aspect of using school operational assistance funds to pay teachers and staff salaries. The results of interviews with school principals and school committee administrators said:

"We always follow the rules for the percentage of the payment of salaries or salaries of teachers and staff in schools by government guidelines, and in fact, we always try to take following the maximum value of the guidelines for the use of school operational assistance funds."

Deconcentration and devaluation, namely the distribution of authority (Santagati et al., 2020) in the form of teacher and staff salaries for schools, are still limited to $50 \%$ of the total budget. Decision making and management authority [2], [5], [6] are limited to $50 \%$ or half of the salary of teachers and school staff. Even the previous year a maximum of $30 \%$ and $15 \%$, while secondary schools and vocational high schools need a different budget from one school to another. With restrictions on the use of funds as in table 1 gives reasons for schools to justify allocating a budget with this provision, even though the school does not need it. Likewise, decentralization in the form of the delegation of authority to schools [1] to make decisions about the number of operational assistance funds tends to be the reason for justification, namely the existence of a percentage limit. The hope of privatization that is free to regulate itself [1] in determining the amount of salary and salary has not been reached.
Deconcentration and devaluation in the use of operational assistance funds have become a triple helix involvement, namely the government, universities, and industry (Muraille, 2020; Shi et al., 2020; Zhou et al., 2020) in the process of channelling school operational assistance funds. Especially his involvement in the organization of the school committee [49]. Like the results of an interview with the head of the school committee saying that:

"It is better for universities, industry, and local government to be the administrators of the school committee, primarily vocational high schools. During this time, we feel the benefits of the existence of higher education because it can help in learning innovation. "'

Higher education has an interest in encouraging the birth of innovation [27] and the quality of prospective students who will continue to university. This industry has an interest in driving the needs of labour and entrepreneurship [6], [26], [30]. District governments have an interest in budget policy allocation [33]. The planning, implementation, monitoring and evaluation process for the use of school operational assistance funds are more effective and efficient. Such conditions can support the limits of deconcentration and devaluation.

Triple-Helix synergy can be applied to analyze sectors where uncertainty is reduced significantly but has the most significant contribution in the next generation [24]. The change referred to here is the high school and vocational high school education sector, not all alumni can continue their education to university, but some directly enter the industry after graduating from school. Likewise, the meaning of a significant contribution to the next generation is that high school and vocational high school alumni also become the younger generation of the workforce which largely determines the future of the nation and state. So that the synergy of universities, industries, and local governments in the process of management of school aid funds in which the number and dominant authority in the aspects of deconcentration and devaluation is expected. Because some research results suggest that, triple helix combines technology, organization, and territoriality [6], [20], [26] to achieve quality and education efficiency.

The triple helix approach will ensure accountability and transparency in the management of school operational assistance funds because they are stakeholders in the education sector, especially in senior high school and vocational high schools. Accountability and transparency in the process of providing services [50], for the quality of educational outcomes [46] which use the budget sourced from public taxes. Transparency and accountability of school leadership [11].

\section{Conclusions}

The process of planning, organizing, directing and 
controlling school operational assistance funds has adopted a decentralized approach. A form of deconcentration and devaluation dominates the decentralization approach. The school principal, teachers, and administrators of the school committee have the authority to determine the amount of use of school operational assistance funds but do not conflict with guidelines for school operational assistance funds established by the Ministry of Education and Culture.

To ensure the efficiency and quality of education that is dominant in the aspects of deconcentration and devaluation is supported by the triple helix synergy, namely universities, industries, and district governments. The triple helix synergy is manifested in the form of involvement in becoming a member of a school committee that has joint authority with the principal in planning, implementing, supervising, and evaluating the use of school operational assistance funds. Triple helix synergy is needed because they are stakeholders of senior high schools and vocational high schools. The implications of the triple helix approach will ensure the accountability and transparency of the service delivery process to the community.

\section{Acknowledgments}

The author thanks Hardianti, Sandy Lubis and Yayuk Astuty for helping as observers in retrieving research data. Furthermore, the study also thanks Muhammadiyah Sidenreng Rappang University, through a research grant program for this Thesis Master research.

\section{REFERENCES}

[1] N. Mcginn, "Decentralization of education: why , when , what and how?," in Decentralization of education: why, when, what and how?, no. January 1999, Published by the United Nations Educational, Scientific and Cultural Organization 7 place de Fontenoy, F 75352 Paris 07 SP, 1999, pp. 1-102.

[2] D. A. Rondinelli, "Government Decentralization in Comparative Perspective," Int. Rev. Adm. Sci., vol. 47, no. 2, pp. 133-145, Jun. 1981.

[3] S. Ponte, C. Noe, and A. Mwamfupe, "Private and public authority interactions and the functional quality of sustainability governance: Lessons from conservation and development initiatives in Tanzania," Regul. Gov., no. January, p. rego.12303, Jan. 2020.

[4] M. E. Santagati, S. Bonini Baraldi, and L. Zan, "Understanding Decentralisation: Deconcentration and Devolution Processes in the French and Italian Cultural Sectors," SSRN Electron. J., 2020.

[5] T. Christensen and L. Ma, "Coordination Structures and Mechanisms for Crisis Management in China: Challenges of
Complexity," Public Organ. Rev., vol. 20, no. 1, pp. 19-36, Mar. 2020.

[6] M. Meyer, J. Kuusisto, K. Grant, M. De Silva, S. Flowers, and U. Choksy, "Towards new Triple Helix organisations? A comparative study of competence centres as knowledge, consensus and innovation spaces," R\&D Manag., vol. 49, no. 4, pp. 555-573, Sep. 2019.

[7] M. Mattes, B. A. Leeds, and R. Carroll, "Leadership Turnover and Foreign Policy Change: Societal Interests, Domestic Institutions, and Voting in the United Nations," Int. Stud. Q., vol. 59, no. 2, pp. 280-290, Jun. 2015.

[8] B. Dineley, S. Munro, and W. V. Norman, "Leadership for success in transforming medical abortion policy in Canada," PLoS One, vol. 15, no. 1, p. e0227216, Jan. 2020.

[9] M. Song, S. An, and K. J. Meier, "Quality standards, implementation autonomy, and citizen satisfaction with public services: cross-national evidence," Public Manag. Rev., vol. 00, no. 00, pp. 1-23, Feb. 2020.

[10] D. Feng, Understanding China's School Leadership Interpreting the Terminology. 2020.

[11] D. Feng, Understanding China's School Leadership. Singapore: Springer Singapore, 2020.

[12] O. Bandiera, M. C. Best, A. Q. Khan, A. Prat, and Working, "The Allocation of Authority in Organizations: A Field Experiment with Bureaucrats," 2020.

[13] T. Clausen, "From decentralized means-testing to the centralized management of stipends and loans. The administration of student financial aid in Denmark 1950 2000," J. Educ. Adm. Hist., vol. 0, no. 0, pp. 1-13, Jan. 2020.

[14] G. Nhamo, G. O. A. Odularu, and V. Mjimba, Scaling up SDGs Implementation. Cham: Springer International Publishing, 2020.

[15] K. Lassoued, A. Awad, and R. Ben Guirat, "The impact of managerial empowerment on problem solving and decision making skills: the case of Abu Dhabi University," Manag. Sci. Lett., vol. 10, no. 4, pp. 769-780, 2020.

[16] L. Breen, J. Acosta-Gómez, J. Tomlinson, K. Medlinskiene, and J. Elies-Gomez, "A preliminary insight into the role and importance of management skills in the prevention of occupational derailment: An exploratory analysis of UK and Spanish pharmacists," Eur. Manag. J., Feb. 2020.

[17] J. B. Heath, "From the Spirit of the Federalist Papers to the End of Legitimacy: Reflections on Gundy V. United States," SSRN Electron. J., vol. 114, pp. 250-274, 2020.

[18] S. Herliana, "Regional Innovation Cluster for Small and Medium Enterprises (SME): A Triple Helix Concept," Procedia - Soc. Behav. Sci, vol. 169, no. August 2014, pp. 151-160, Jan. 2015.

[19] H. Zhou, Y. Ma, and S. Wei, "A Promotion Mode for the Development of Advanced Manufacture with Legislation in USA," in Proceedings of the International Academic Conference on Frontiers in Social Sciences and Management Innovation (IAFSM 2019), 2020, vol. 403, no. Iafsm 2019, pp. 307-314.

[20] H. Etzkowitz and L. Leydesdorff, "The dynamics of innovation: from National Systems and 'Mode 2' to a Triple 
Helix of university-industry-government relations," Res. Policy, vol. 29, no. 2, pp. 109-123, Feb. 2000.

[21] A. D. Matraeva, M. V. Rybakova, M. V. Vinichenko, A. A. Oseev, and N. V. Ljapunova, "Development of Creativity of Students in Higher Educational Institutions: Assessment of Students and Experts," Univers. J. Educ. Res., vol. 8, no. 1, pp. 8-16, Jan. 2020.

[22] X. Shi, Y. Wu, and D. Fu, "Does University-Industry collaboration improve innovation efficiency? Evidence from Chinese Firms $\diamond, "$ Econ. Model., vol. 86, no. February, pp. 39-53, Mar. 2020.

[23] E. Muraille, "Ethical control of innovation in a globalized and liberal world: Is good science still science?," Endeavour, vol. 2, no. 1, p. 100709, Feb. 2020.

[24] W. Glänzel, H. F. Moed, U. Schmoch, and M. Thelwall, Springer Handbook of Science and Technology Indicators. Cham: Springer International Publishing, 2019.

[25] A. Altaf, I. e. Hassan, and S. Batool, "The role of ORIC in the evolution of the triple helix culture of innovation: The case of Pakistan," Technol. Soc., vol. 56, pp. 157-166, Feb. 2019.

[26] N. Yoda and K. Kuwashima, "Triple Helix of UniversityIndustry-Government Relations in Japan: Transitions of Collaborations and Interactions," J. Knowl. Econ., Mar. 2019.

[27] M. Blankesteijn, B. Bossink, and P. van der Sijde, "Science-based entrepreneurship education as a means for university-industry technology transfer," Int. Entrep. Manag. J., Jan. 2020.

[28] A. H. Samo and N. U. Huda, "Triple Helix and academic entrepreneurial intention: understanding motivating factors for academic spin-off among young researchers," J. Glob. Entrep. Res., vol. 9, no. 1, p. 12, Dec. 2019.

[29] O. V. Danilova, "Speech Culture Development in Engineering Students in the Modern Education System," in Proceedings of the International Session on Factors of Regional Extensive Development (FRED 2019), 2020, vol. 113, no. Fred 2019, pp. 26-29.

[30] Y. Cheng, Y. Liu, W. Fan, Z. Yan, and X. Ye, "Triple helix on globalization: A case study of the China International Nanotech Innovation Cluster," Inf. Dev., vol. 35, no. 2, pp. 272-289, Mar. 2019.

[31] M. Carmen, "PRACTICAL APPLICABILITY OF THE DELEGATION OF POWERS IN ( An approach to the questions raised in Spanish Law )," SPANISH J. Legis. Stud., vol. 1, pp. 1-27, 2019.

[32] S. L. Hartati and S. Purba, "The Influences of Principal's Supervision, Teacher's Empowerment, Achievement Motivation on Teacher's Organizational Commitment at the Junior High School," 2020, vol. 400, no. Icream 2019, pp. $12-16$.

[33] A. Nurmandi, Z. Qodir, H. Jubba, and D. Mutiarin, "ELITE CAPTURE OF BUDGET CORRUPTION," PUBLIC POLICY Adm., vol. 19, no. 2, pp. 340-353, 2020.

[34] P. A. Johnson, P. J. Robinson, and S. Philpot, "Type, tweet, tap, and pass: How smart city technology is creating a transactional citizen," Gov. Inf. Q., vol. 37, no. 1, p. 101414 , Jan. 2020.

[35] E. Merkaj, R. Lucchetti, and F. Fiorillo, "The role of local leaders in regional development funding: Evidence from an elite survey," J. Reg. Sci., vol. xx, no. December 2018, pp. $1-26,2020$.

[36] E. Sá, B. Casais, and J. Silva, "Local development through rural entrepreneurship, from the Triple Helix perspective," Int. J. Entrep. Behav. Res., vol. 25, no. 4, pp. 698-716, Jun. 2019.

[37] D. Hidayati, "Quality Curriculum Models for the Millennial," in Proceedings of the 3rd International Conference on Research of Educational Administration and Management (ICREAM 2019), 2020, vol. 400, no. Icream 2019, pp. 236239.

[38] D. Baghdasarin, "Aviation Maintenance Instructional Design: How to Teach the Millennial and Gen-Z Cohorts," Int. J. Aviat. Aeronaut. Aerosp., vol. 7, no. 1, p. 3, 2020.

[39] H. Harwanto, N. R. Nuari, and P. Christian, "The Effect of Brand Image, Variety-Seeking Tendency, and Peer Influence to Promotional Activity Interest and Its Effect to Purchaseintention on Millennials," Int. J. Res. Rev., vol. 7, no. February, pp. 208-213, 2020.

[40] P. A. Ebeling, D. L. Dent, and J. W. Kempenich, "The millennials have arrived: What the surgeon educator needs to know to teach millennials," Surgery, vol. 167, no. 2, pp. 265-268, Feb. 2020.

[41] A.-S. T. Olanrewaju, M. A. Hossain, N. Whiteside, and P. Mercieca, "Social media and entrepreneurship research: A literature review," Int. J. Inf. Manage., vol. 50, no. November 2018, pp. 90-110, Feb. 2020.

[42] Kustomo and K. Hasyim, "The Effectiveness of the Role of State Senior High School Committee in Jombang Regency East Java Indonesia," KnE Soc. Sci., vol. 2020, no. 3, pp. 152-157, Feb. 2020.

[43] R. Aryanti and D. Suhardan, "Principal Leadership and School Committee Administrators Against School-Based Management Effectiveness," in Proceedings of the 3rd International Conference on Research of Educational Administration and Management (ICREAM 2019), 2020, vol. 400, no. Icream 2019, pp. 151-152.

[44] E. Joram, A. J. Gabriele, and K. Walton, "What influences teachers' 'buy-in' of research? Teachers' beliefs about the applicability of educational research to their practice," Teach. Teach. Educ., vol. 88, no. October, p. 102980, Feb. 2020.

[45] A. W. Marré and A. Rupasingha, "School quality and rural in-migration: Can better rural schools attract new residents?," J. Reg. Sci., vol. 60, no. 1, pp. 156-173, Jan. 2020.

[46] D. N. Ammons and D. J. Roenigk, "Exploring Devolved Decision Authority in Performance Management Regimes: The Relevance of Perceived and Actual Decision Authority as Elements of Performance Management Success," Public Perform. Manag. Rev., vol. 43, no. 1, pp. 28-52, Jan. 2020.

[47] Y. Zhang, S. Kant, and H. Long, "Collective Action Dilemma after China ' s Forest Tenure Reform: Operationalizing Forest Devolution," Land, vol. 9, no. 58, pp. 1-18, 2020. 
[48] S. N. S. Ishak and Suyatno, "Teacher performance, parent's role, and student learning outcomes in muhammadiyah junior high school," Univers. J. Educ. Res., vol. 8, no. 2, pp. 529-539, 2020.

[49] Z. Zahraini and B. Situmorang, "The Formulation of the Principals' Policies in Improving Teacher Professionalism in
Senior High Schools in North Sumatra," Univers. J. Educ. Res., vol. 8, no. 7, pp. 2898-2906, Jul. 2020.

[50] I. Fyshchuk, "EFFECTIVE COMMUNICATION IN DIGITAL TRANSFORMATION OF SERVICE STATE DURING," PUBLIC POLICY Adm., vol. 19, no. 2, pp. 172190, 2020 